E-ISSN 2347-2677 P-ISSN 2394-0522 www.faunajournal.com IJFBS 2021; 8(6): 01-06 Received: 16-07-2021

Accepted: 03-09-2021

Saumen Chakrabarti Department of Zoology, Women's College, Agartala, Tripura, India
Corresponding Author: Saumen Chakrabarti Department of Zoology, Women's College, Agartala, Tripura, India

\section{A comparative study on the density and seasonal variations of rotifer and copepod fauna in a pond of Tripura, India with a note on water quality parameters}

\section{Saumen Chakrabarti}

DOI: https://doi.org/10.22271/23940522.2021.v8.i6a.855

\begin{abstract}
A Comparative study was carried out in a pond of Tripura to observe the density and seasonal succession of rotifer and copepod fauna and the observation recorded 26 species of rotifer and 6 species of copepod fauna. Percentage composition of different families as well as the percentage composition of each species in the recorded total rotifer and copepod fauna were also noted. Rotifer fauna showed maximum density in the winter and minimum density during the summer. On the contrary, copepod fauna showed maximum density in the summer and minimum density in monsoon season. Rotifer fauna showed significant positive correlation with water temperature, free carbon dioxide, total alkalinity, nitratenitrogen, phosphate phosphorus and negative correlation with transparency. On the contrary, copepod fauna showed positive correlation with water temperature and $\mathrm{pH}$ and negative correlation with dissolved oxygen, total alkalinity and nitrate nitrogen. The observation infers that the densities of rotifer and copepod fauna varies with the seasons, which might be the dynamic nature of the aquatic ecosystem and might also be due to optimal condition in the water quality parameters of the studied pond ecosystem.
\end{abstract}

Keywords: Rotifer density, copepod density, percentage composition, seasonal variations, water quality factors, pond ecosystem, Tripura

\section{Introduction}

The seasonal occurrence and abundance of rotifers are dependent on the co-joint interactions of biotic and abiotic (physico-chemical) factors (Dumont 1977; Mikschi 1989; Castro 2005) [14, 29, 9]. El-Shabrawy and Germoush (2014) ${ }^{[16]}$ opined that in aquatic ecosystems, the community structure of rotifers varies with the season often with the succession of different dominant species. Nogrady et al.(1993) [32] stated that in aquatic ecosystems, rotifers react faster to changes in water quality parameters as compared to other freshwater zooplankton due to possession of their short development cycle ( $r$ strategists). In aquatic ecosystems, rotifers play key role in the energy flow and nutrient cycling, especially when the abundance of crustacean zooplankton is low (Sanders 1989) ${ }^{[38]}$. Rotifers having predatory behaviour are capable of regulating the populations of phytoplankton, protozoans and bacteria in aquatic ecosystem (Lubzens et al. 1989) ${ }^{[23]}$. Rotifers have gained great ecological importance in freshwater lentic ecosystems due to their ability to colonize diversified aquatic and semi-aquatic habitats and the majority of them are cosmopolitan in distribution (Paggi 1990) ${ }^{[33]}$. In aquatic ecosystems, rotifers on having inherent quality to build up substantial densities within short time intervals are considered as a valuable tool for population dynamic studies (Andrew and Fitzsimons 1992). Several noteworthy researchers (Sládeček 1983; May and O’Hare 2005; Gutkowska et al. 2013) ${ }^{[44,27,19]}$ reported that rotifer species composition, total abundance and diversity indices (such as Brachionus: Trichocerca ratio, Keratella-index) have widely been used for the assessment of trophic status in aquatic ecosystem. Copepods are common zooplankton of aquatic ecosystem (fresh water and brackish water) and play very important role as prey for many juvenile and adult zooplanktivorus fish and (Evjemo et al. 2003; Vaidya 2017) ${ }^{[18,47]}$. In eutrophic water bodies, copepods remain in dominating stage as they are very sensitive to the availability of food resource (Sommer and Stibor 2002) ${ }^{[45]}$. Santer (1993) ${ }^{[39]}$ stated that the dominancy of cyclopoid copepod is the indication of abundant availability of diatoms (Bacillariophyceae) and blue green algae (Cyanophyceae) in freshwater lentic water bodies. Peter and Gerhard (1992) ${ }^{[35]}$ reported that copepod play important role in the consumption of carbon produced by the microbial loop. In aquatic ecosystem, copepods, in general can withstand harsher environmental conditions as compared to other zooplankton (Meshram 
2014) ${ }^{[28]}$

The seasonal occurrence and abundance of copepods are related to abiotic (such as water temperature, turbidity) and biotic parameters (such as competition, predation, food habits and food availability) or a combination of both (Dieguez and Gilbert 2002; Shah and Pandit 2013) [32, 41]. Aquatic macrophytes play a crucial role by offering a variety of microhabitats which are used as refuges against visual predators for many zooplankton species ((Kuczynska-Kippen and Nagengast 2003) [22]. Ponds constitute biodiversity "hot spots" within a region or landscape and density of zooplankton is quite high in the fertile lentic water body like a pond. (Madhusudhana et al. 2014) ${ }^{[24]}$. Ponds habitats are frequently subjected to pollution stresses due to their shallowness and small area provides the limitation to buffering capacity as compared to lakes and rivers (Schffer et al. 2006) ${ }^{[40]}$. In Tripura, Banik $(1995,1996)^{[4,5]}$ worked on sessile rotifers and reported some sessile rotifer species from fish ponds of Tripura. Chakrabarti (2013) [10] reported seasonal abundance of crustacean community in a pond ecosystem of Tripura. In Tripura, however, no comparative studies between the rotifer and copepod fauna with reference to the density and seasonal variations have been reported till date. Hence, in the present study, a comparative account was undertaken to observe the density and seasonal variations of rotifer and copepod fauna and also observe the influence of water quality factors on the densities of rotifer and copepod fauna in a pond ecosystem of Tripura, India.

\section{Materials and Methods}

The study was performed in a freshwater pond located at Jogendranagar, Agartala, West District of Tripura, India from March 2019 to February 2021. Geographically, the studied water body lies at Latitude $23^{\circ} 50^{\prime} 9.78^{\prime \prime} \mathrm{N}$ and Longitude $91^{\circ}$ 16' 45.80" E. The observable pond is shallow, rectangular shaped and perennial. The total surface area of the pond is about 0.76 ha. The depth of the water column in the studied pond fluctuates from $1.0 \mathrm{~m}$ to $2.5 \mathrm{~m}$. The littoral area of the water body harbours some macrophytes such as Eichhornia crassipes and Salvinia sp. The studied pond is used for scientific rearing of Indian major carps. The rotifer and copepod fauna have been collected by filtering 100 litre surface water through plankton net (mesh size $50 \mu \mathrm{m}$ ) at weekly intervals and fixed immediately with $4 \%$ formalin and enumeration is done in the laboratory under the microscope through Sedgwick Rafter Plankton Counting Cell and results were expressed as individual per litre (ind/l). The rotifer fauna were identified up to species level following keys of Pennak (1978) ${ }^{[34]}$ and Edmondson (1992) ${ }^{[15]}$. Copepod fauna were identified up to species level following keys of Battish, (1992) [6]. Aquatic macrophytes were identified following keys of Cook (1996) [11] Water quality parameters such as transparency, water temperature, $\mathrm{pH}$ were determined on the field site and the other limnological parameters viz., dissolved oxygen, free carbon dioxide, alkalinity, dissolved organic matter, silicate, phosphate phosphorus and nitrate nitrogen were analysed in the laboratory following methodology of APHA (2012) ${ }^{[3]}$ Pearson's correlation coefficient(r) was done in order to know the degree of influence of water quality factors on the density of rotifer and copepod fauna in the studied pond water. The statistical software (SPSS version 1.5) was used for the statistical analysis.

\section{Results and Discussion}

The present observation recorded 26 species of rotifer and 6 species of copepod fauna. The recorded rotifer species are Brachionus angularis, Brachionus bidentata, Brachionus caudatus, Brachionus falcatus, Brachionus forficula, Brachionus quadridentatus, Brachionus urceolaris, Brachionus rubens, Brachionus diversicornis, Keratella tropica, Keratella cochlearis, Anuraeopsis fissa, Lecane luna, Lecane depressa, Lecane ungulata, Monostyla bulla, Lepadella ovalis, Lepadella patella, Colurella uncinata, Trichocerca longiseta, Trichocerca cylindrica, Polyarthra vulgaris, Mytilina ventralis, Euchlanis dilatata, Testudinella patina and Asplanchna priodonta. On the contrary, the recorded six copepod species are Mesocyclops leuckarti, Mesocyclops hyalinus, Mesocyclops edax, Paracyclops fimbriatus, Eucyclops agilis and Heliodiaptomus viduus.

The recorded 26 species of rotifers belongs under 13 genera and 9 families. Quantitative analysis showed that Brachionidae is the dominant family with 12 species followed by Lecanidae with 4 species, Colurellidae with 3 species, Trichocercidae with 2 species, while Synchaetidae, Mytilinidae, Euchlanidae, Testunellidae and Asplanchnidae have 1 species each, thus contributing $43 \%, 15 \%, 11 \%, 9 \%$, $8 \%, 4 \%, 3 \%, 5 \%$ and $2 \%$ respectively to the total recorded rotifer fauna in the studied pond (Fig 1).

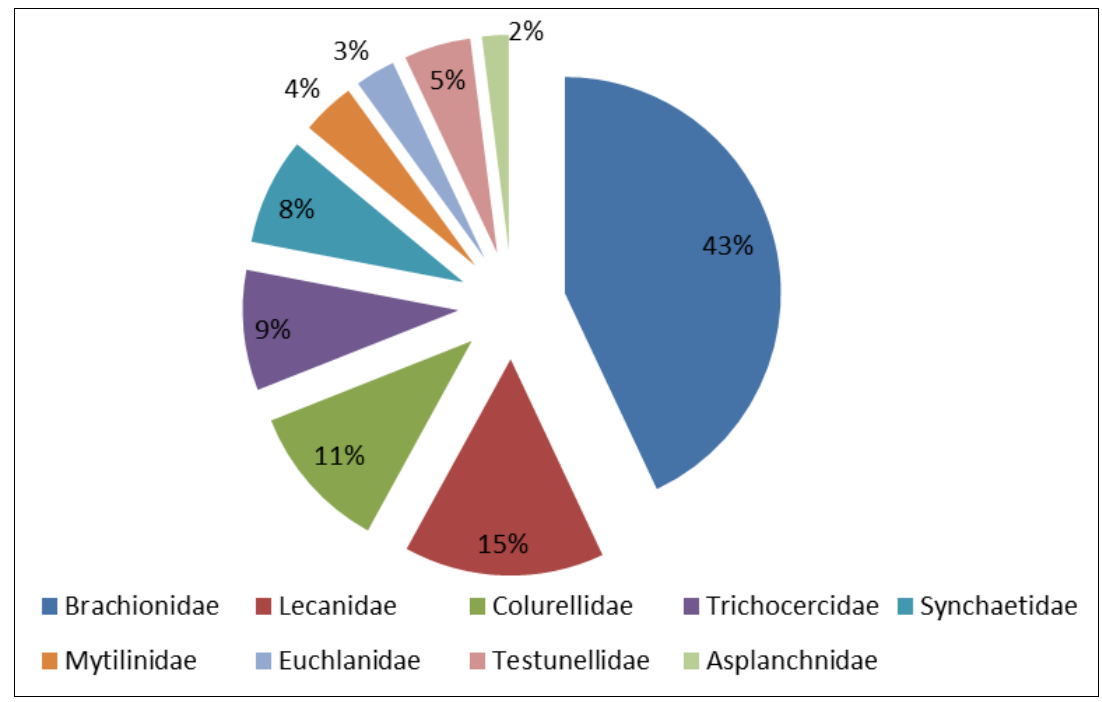


Fig 1: The percentage composition of different families of the rotifer fauna in the studied pond

The percentage composition of the Brachionus angularis, Brachionus bidentata, Brachionus caudatus, Brachionus falcatus, Brachionus forficula, Brachionus quadridentatus, Brachionus urceolaris, Brachionus rubens, Brachionus diversicornis, Keratella tropica, Keratella cochlearis and Anuraeopsis fissa under the family Brachionidae were 5\%, $2 \%, 4 \%, 2 \%, 9 \%, 2 \%, 3 \%, 2 \%, 3 \%, 6 \%, 3 \%$ and $2 \%$ respectively. The percentage composition of the Lecane Luna, Lecane depression, Lecane ungulate and Monostyla bullet under the family Lecanidae were $6 \%, 2 \%, 3 \%$ and $4 \%$ respectively. The percentage composition of the Lepadella ovals, Lepadella patella and Colurella uncinata under the family Colurellidae were $5 \%, 2 \%$ and $4 \%$ respectively. The percentage composition of the Trichocerca longiseta and Trichocerca cylindrica were $7 \%$ and $2 \%$ respectively. The percentage composition of Polyarthra vulgaris under the family Synchaetidae was $8 \%$. The percentage composition of Mytilina ventralis under the family Mytilinidae was $4 \%$. The percentage composition of Euchlanis dilatata under the family Euchlanidae was 3\%. The percentage composition of the Testudinella patina under the family Testunellidae was $5 \%$, while the percentage composition of Asplanchna priodonta was $2 \%$ (Fig 2).

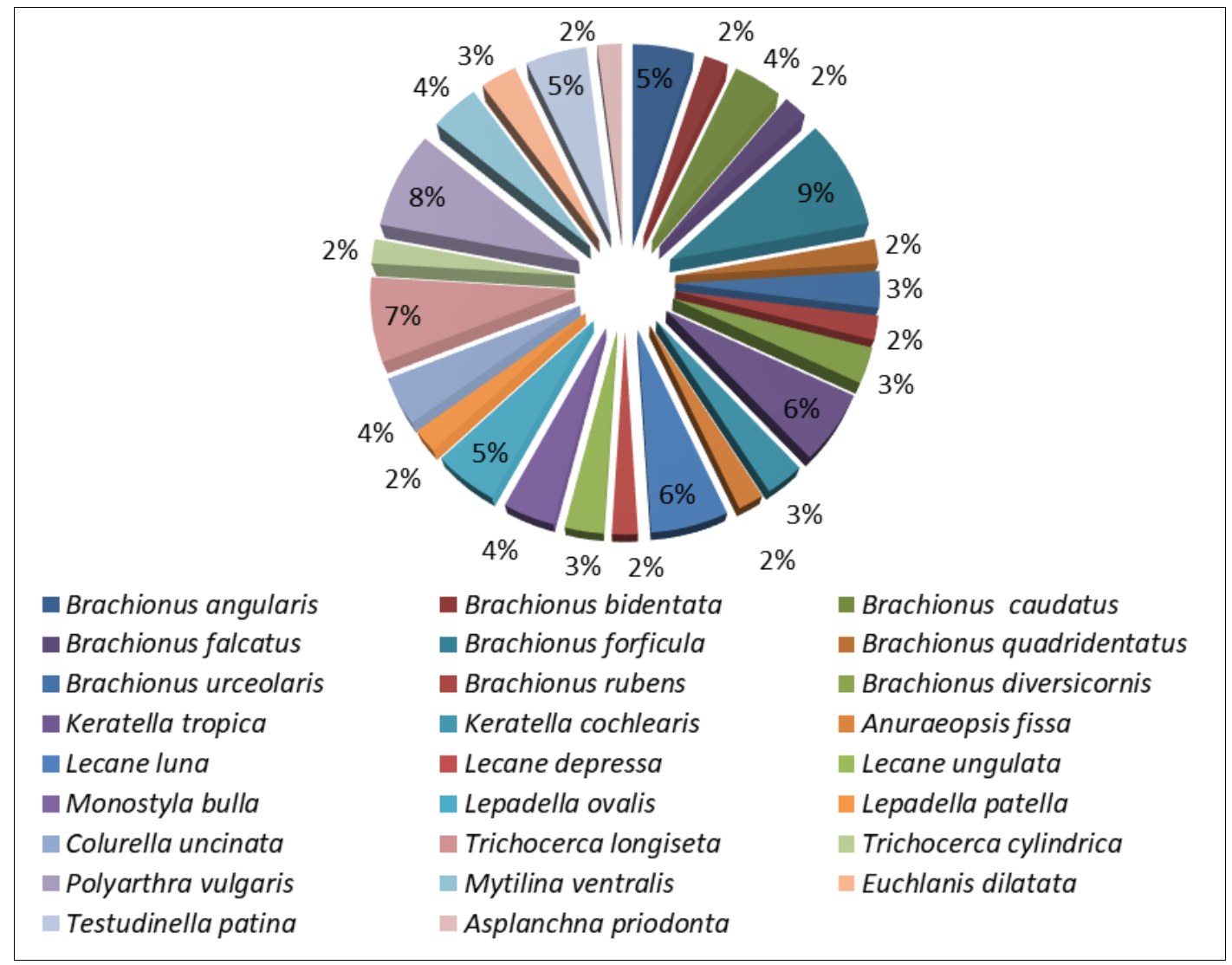

Fig 2: The percentage composition of each species of then total rotifer population in the studied pond

On the contrary, the present study recorded the presence of 6 species of copepod fauna which belongs under 4 genera and 2 families. The quantitative study showed that Cyclopidae is the dominant with 4 species followed by Diaptomidae with only 1 species, thus contributing $89 \%$, and $11 \%$ respectively of the total copepod fauna (Fig 3)

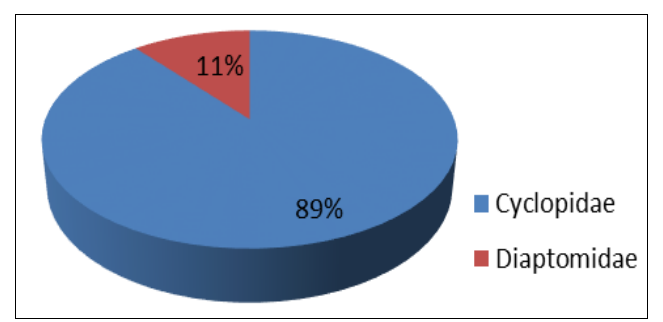

Fig 3: The percentage composition of different families of the copepod fauna in the studied pond

The percentage composition of Mesocyclops leuckarti, Mesocyclops hyalinus, Mesocyclops edax, Eucyclops agilis and Paracyclops fimbriatus belongs under the family Cyclopidae were $37 \%, 15 \%, 23 \%, 9 \%$ and $5 \%$ respectively. The percentage composition of Heliodiaptomus viduus belongs under the family Diaptomidae was 11\% (Fig 4).

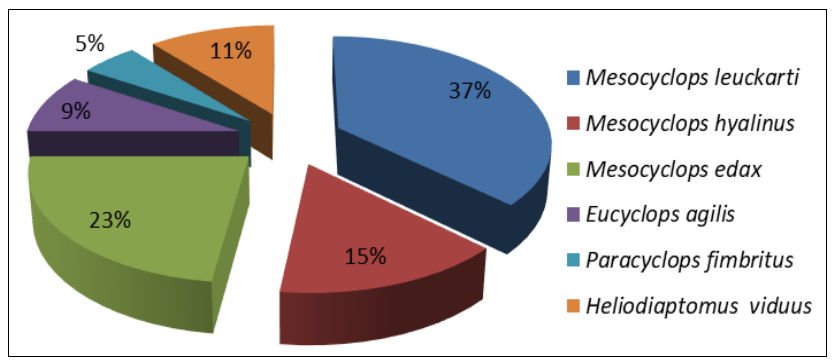

Fig 4: The percentage composition of each species of then total copepod population in the studied pond

Rotifer fauna showed maximum density (631ind/l) in the winter and minimum density (119 ind/l) during summer of the two observable study periods. On the contrary, copepod fauna 
showed maximum density (273 ind/l) in the summer and minimum density (59 ind/l) in monsoon season (Fig 5).

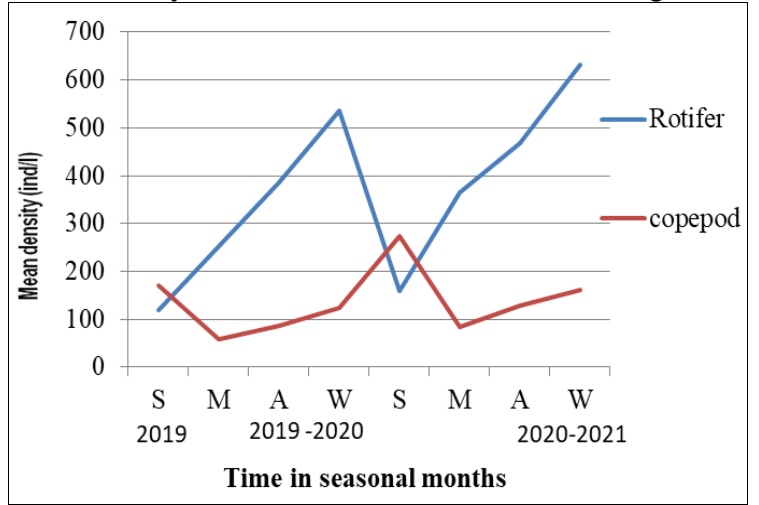

Fig 5: Seasonal variations of rotifer and copepod fauna in the studied pond

Abbreviation Used: $\mathrm{S}=$ Summer (March-May); $\mathrm{M}=$ Monsoon (JuneAugust); A= (September-October); W=Winter (November-February)

Researchers (Hofmann 1977; Berzins and Pejler 1987; Dangne et al., 2007; Sivakami et al., 2013) ${ }^{[20,7,12,43]}$ stated that maximum density of rotifers in winter due to availability of plenty food in addition to optimal conditions of some water quality parameters such as water temperature, $\mathrm{pH}$, dissolved oxygen etc. Minimum density of rotifers in summer might be due to lower concentration of dissolved organic matter and insufficient live food biota (Mahar, et al. 2000; Castro, et al. 2005) [25, 9]. Meshram, (2014) [28] opined that maximum density of copepod fauna in summer may be due to availability of plenty live food and competition with other species. However, Bhuiyan, et al. (2008) ${ }^{[8]}$ stated that the effect of over fishing might be the probable reason for a maximum density of copepod fauna during summer season. Lowest density of copepod fauna during monsoon is the dilution effect and as such some physico-chemical factors like lower water temperature, $\mathrm{pH}$, salinity and TDS are not in favour for the growth and survivability of copepod fauna (Maruthanayagam 2008; Pramod et al. 2011; Kavitha et al. 2016) ${ }^{[36,21]}$.

Kuczynska-Kippen and Nagengast (2003) ${ }^{[22]}$ stated aquatic macrophytes play key role in conditioning specific assemblages of rotifer in aquatic ecosystems. Rundle and Ormerod (1992) [37] opined that amongst copepod fauna, numerical abundance of cyclopoids are noticed in such lentic water bodies that are highly weed infested. Nilssen and Waervagen (2002) stated that Mesocyclops leuckarti, a cyclopoid species commonly found in weed infested lentic water bodies utilize periphytic and detritus food sources which are available in plenty amount in such water bodies.

The present study reveals numerical abundance of rotifer and copepod fauna in and around the aquatic macrophytes than the exposed littoral zones in the observable pond. Nayar and Nair (1969) ${ }^{[30]}$ and Sharma (1983) ${ }^{[42]}$ stated that the numerical abundance of rotifers are dependent upon the availability of algal food and the metabolic products of aquatic macrophytes which con-jointly forms suitable ecological niche for the rotifers. Stewart and George (1987) stated that in aquatic ecosystem, the lower availability of rotifers in the vegetation free exposed littoral zone was the impact of sunlight factor. Water quality parameters of the studied pond water were noted in Table 1.

Table 1: Water quality parameters of the studied pond

\begin{tabular}{|c|c|c|}
\hline Water Quality factors & Range & Mean \\
\hline Water temperature $\left({ }^{\circ} \mathrm{C}\right)$ & $10-36$ & 28 \\
\hline Transparency $(\mathrm{cm})$ & $8-20$ & 12 \\
\hline $\mathrm{pH}$ & $5.6-9.2$ & 7.4 \\
\hline Dissolved oxygen $(\mathrm{ppm})$ & $5.2-7.8$ & 6.2 \\
\hline Free carbon dioxide( $\mathrm{ppm})$ & $1.2-2.6$ & 1.4 \\
\hline Alkalinity $(\mathrm{ppm})$ & $74-152$ & 110 \\
\hline Dissolved organic matter(ppm) & $11.4-22.6$ & 16.2 \\
\hline Silicate $(\mathrm{ppm})$ & $8.2-15.4$ & 12.4 \\
\hline Phosphate phosphorus(ppm) & $0.01-0.2$ & 0.09 \\
\hline Nitrate nitrogen $(\mathrm{ppm})$ & $0.01-0.2$ & 0.07 \\
\hline
\end{tabular}

During the study, the optimal numerical abundance of rotifers was noticed in the temperature range between $12-28{ }^{\circ} \mathrm{C}$. However, three main types of rotifer responses to temperature were also observed. High temperature $\left(28-32^{\circ} \mathrm{C}\right)$ preferred species of rotifer includes Brachionus forficula, Brachionus falcatus, Lecane luna, Lecane depressa, Lecane ungulate, Testudinella patina. Moderate temperature $\left(22-25 \quad{ }^{\circ} \mathrm{C}\right)$ preferred species of rotifer includes Anuraeopsis fissa, Keratella tropica, Monostyla bulla, Trichocerca longiseta, Trichocerca cylindrica, Polyarthra vulgaris, Euchlanis dilatata. Low temperature $\left(12-15{ }^{\circ} \mathrm{C}\right)$ preferred species of rotifer includes Asplanchna priodonta, Keratella cochlearis, Brachionus calyciflorus. Surprisingly, abundance of Brachionus angularis was observed in both the low temperature and moderate temperature values. On the contrary, the optimal numerical abundance of copepod fauna was observed in the temperature range between $29-33{ }^{\circ} \mathrm{C}$. Mesocyclops leuckarti, the super dominant copepod species reached a peak population at about $31^{\circ} \mathrm{C}$ and its population was completely disappeared at a temperature below $14{ }^{\circ} \mathrm{C}$. The present observation showed that copepod fauna were dominant in warmer period of the year. Bhuiyan, et al. (2008) ${ }^{[8]}$ emphasized the role of temperature on crustacean densities. Bhuiyan, et al. (2008) ${ }^{[8]}$ reported that temperature on one hand, acting directly for accelerating the growth rates of crustacean zooplankton, which in turn increases the population densities of crustaceans and on the other hand, it hastens the growth of phytoplankton population which serves as live food for crustacean zooplankton. Shah and Pandit, (2013) ${ }^{[41]}$ reported that the density of copepod was less when the concentration of nitrate was more. In the present study, the concentration of nitrate nitrogen ranged between 0.01-0.02 (Table 1). In the present observation, the highest density of rotifer zooplankton was recorded in the $\mathrm{pH}$ range of 6.8-7.4 and dissolved oxygen concentration of 5.6 to $6.8 \mathrm{ppm}$. During observation, it was found that Monostyla bulla was available only in low oxygen concentration. On the contrary, the highest density of copepod zooplankton was recorded in the $\mathrm{pH}$ range of 5.8 to 6.4 and dissolved oxygen concentration of 5.4 to $6.0 \mathrm{ppm}$.

Pearson's correlation coefficient (r) has also done in order to know the degree of influence of water quality factors on the densities of rotifer and copepod fauna in the studied pond water (Table 2). 
Table 2: Correlation of rotifer and copepod fauna with water quality factors in the studied pond

\begin{tabular}{|c|c|c|c|c|c|c|c|c|}
\hline Groups & WT & Tr & pH & DO & FCO $_{2}$ & TA & NO $-\mathbf{N}$ & PO4-P \\
\hline Rotifer & $.523^{* *}$ & $-.437^{* *}$ & .357 & .431 & $.419^{*}$ & $.459^{* *}$ & $.351^{*}$ & $.413^{*}$ \\
\hline Copepod & $.317^{*}$ & .291 & $.259 *$ & $-.313^{*}$ & .321 & $-.423^{* *}$ & $-.471 *$ & .359 \\
\hline
\end{tabular}

* Significant at the $5 \%$ level (2-tailed); ** Significant at the $1 \%$ level (2-tailed) Abbreviation WT: Water temperature, Tr: Transparency, DO: Dissolved oxygen, $\mathrm{FCO}_{2}$ : Free carbon dioxide, TA: Total alkalinity, $\mathrm{NO}_{3}-\mathrm{N}$ : Nitrate-nitrogen, $\mathrm{PO}_{4} \mathrm{P}$ : $\mathrm{Phosphate-phosphorus}$

In the present study, rotifer fauna showed significant positive correlation with water temperature $(\mathrm{r}=.523, P<0.01)$, free carbon dioxide $(\mathrm{r}=.419, P<0.05)$, total alkalinity $(\mathrm{r}=.459, P<$ $0.01)$, nitrate-nitrogen $(\mathrm{r}=.351, P<0.05)$ and phosphate phosphorus $(\mathrm{r}=.413, \quad P<0.05)$. Several noteworthy researchers (Hofmann 1977; Mikschi 1989; Castro et al. 2005; Wang 2016) [20,30,9,48] also observed similar findings. However, this group showed significant negative correlation with transparency $(\mathrm{r}=-.437, P<0.01)$. Rotifer fauna did not depict any significant correlation with $\mathrm{pH}$ and dissolved oxygen. On the contrary, copepod fauna showed positive correlation with water temperature $(\mathrm{r}=.317, P<0.05)$ and $\mathrm{pH}$ $(\mathrm{r}=.259, P<0.01)$. Researchers (Bhuiyan, et al. 2008; Meshram 2014; Apaydin, et al. 2016) ${ }^{[8,28,2]}$ also observed similar findings. Copepod fauna showed negative correlation with dissolved oxygen $(\mathrm{r}=-.313, P<0.05)$, total alkalinity $(\mathrm{r}$ $=-.423, P<0.01)$ and nitrate nitrogen $(\mathrm{r}=-.471, P<0.05)$. Shah and Pandit (2013) ${ }^{[41]}$ also observed that copepod fauna were negatively correlated with dissolved oxygen, alkalinity and nitrate nitrogen. However, copepod fauna did not depict any significant correlation with transparency, free carbon dioxide and phosphate phosphorus (Table 2).

\section{Conclusion}

Thus, the present observation infers that rotifer and copepod fauna although have different environmental requirements, many of them co-exist in the same pond, their densities varies with seasons which might be the dynamic nature of the aquatic ecosystem and might also be due to optimal condition in the water quality parameters of the studied pond ecosystem. The ecological niches in an aquatic ecosystem are very plastic and are likely to be fluctuate widely which in-turn influence in the composition and abundance of rotifer and copepod fauna. A particular population of rotifer and copepod is able to exploit its ecological niches to its maximum and the peaks of rotifer and copepod fauna are, therefore due to differential ecological niches in the studied pond ecosystem. So, in the light of present study, it can be concluded that not a single factor but several factors con-jointly governs on the densities of rotifer and copepod zooplankton in the studied pond ecosystem.

\section{Acknowledgements}

The author expresses his deepest sense of gratitude and obligation to the Principal, Women's College, Agartala, Tripura for providing laboratory facility.

\section{References}

1. Andrew TE, Fitzsimons AG. Seasonality, population dynamics and production of planktonic rotifers in Lough Neagh, Northern Ireland. Hydrobiologia. 1992;246:147164.

2. Apaydın Yağcı M, Yağcı A, Dölcü B. Relationships between the physicochemical parameters and zooplankton in Eğirdir Lake (Turkey) Iranian Journal of
Fisheries Sciences. 2016;15(1):118-132.

3. APHA Standard Methods for the Examination of Water and Wastewater. 22nd ed., APHA-AWWA-WEF, Washington, DC, 2012.

4. Banik S, Kar S. New records of sessile rotifers from freshwater fishponds of Tripura. Proc. India natn. Sci Acad. 1995;B61:225-230.

5. Banik S. New records of sessile rotifers from freshwater fishponds of Tripura II. Proc. India Natn. Sci Acad. 1996;B62:111-116.

6. Battish SK. Freshwater zooplankton of India. Oxford and IBH Publishing Co., New Delhi 1992, 232.

7. Berzins B, Pejler B. Rotifer occurrence in relation to $\mathrm{pH}$. Hydrobiologia. 1987;182:171-182.

8. Bhuiyan AS, Islam MT, Sharmeen R. Occurrence and abundance of some copepods in a fish pond in Rajshahi, Bangladesh in relation to the physico-chemical conditions. J bio-Sci. 2008;16:115-119.

9. Castro B, Antunes SC, Pereira R, Sores AM, Goncalves F. Rotifer community structure in three shallow lakes: Seasonal fluctuations and explanatory factors. Hydrobiologia. 2005;543:221-232.

10. Chakrabarti Saumen. Seasonal abundance of crustacean community in a pond ecosystem of Tripura in relation to physico-chemical factors. Uttar Pradesh J Zool. 2013;33(3):311-316.

11. Cook CDK. Aquatic and Wetland Plants in India. Oxford University Press, Oxford, 1996, 385.

12. Dangne Admnch, Herzig Alois, Jersabek Christian D, Tadesse Zenebe. Abundance, species composition and spatial distribution of planktonic rotifers and crustaceans in Lake Ziway (Rift Valley, Ethiopia). International Review of Hydrobiology. 2007;93(2):210-226.

13. Dieguez MC JJ. Gilbert Suppression of the rotifer Polyarthra remata by the omnivorous copepod Tropocyclops extensus: predation or competition? Journal of Plankton Research. 2002;24:359-369.

14. Dumont JIJ. Biotic factors in the population dynamics of rotifers. Arch. Hydrobiol. Beih. Ergebn. Limnol. 1977;8:98-122.

15. Edmondson WT. Rotifera. In: Freshwater Biology (Edmondson, W.T. Ed.) John Wiley and Sons, New York. 1992.

16. El-Shabrawy GM, Germoush MOA. Seasonal changes and abundance of rotifers in a shallow Manzalah lake (Egypt). Ecohydrol Hydrobiol. 2014;14(3):243-252.

17. Estlander S, Nurminen L, Olin M, Vinni M, Horppila J. Seasonal fluctuations in macrophyte cover and water transparency of four brown-water lakes: Implications for crustacean zooplankton in littoral and pelagic habitats. Hydrobiologia. 2009;620:109-120.

18. Evjemo JO, Reitan KI, Olsen Y. Copepods as live food organisms in the larval rearing of halibut larvae (Hippoglossus hippoglossus L.) with special emphasis on the nutritional value. Aquaculture. 2003;227(1-4):191- 
210.

19. Gutkowska A, Paturej E, Kowalska E. Rotifer trophic state indices as ecosystem indicators in brackish coastal waters. Oceanologia. 2013;55:887-899.

20. Hofmann W. The influence of abiotic factors on the population dynamics in planktonic rotifers. Arch. Hydrobiol. Beih. Ergebn. Limol. 1977;8:77-83.

21. Kavitha A, Amirthanayagi K, Radhika S. Raveendran Qualitative plankton of a managed and unmanaged pond of Anaikkadu, Thanjavur District, Tamil Nadu, India. Int. J Zool. Appl. Biosci. 2016;1(5):236-239.

22. Kuczy'nska-Kippen N, Nagengast Barbara. The impact of the spatial structure of hydromacrophytes on the similarity of rotifera communities (Budzy'nskie Lake, Poland). Hydrobiologia. 2003;506-509:333-338.

23. Lubzens EA, Tandler Minkoff G. Rotifers as food in aquaculture. Hydrobiologia. 1989;186/187;387-400.

24. Madhusudhana Rao R, Krishna PV, Jyothirmayi V, Hemanth Kumar V. Biodiversity of zooplankton communities in a perennial pond at Lake Kolleru Region of Andhra Pradesh, India. Int. J Adv. Res. 2014;2(7):3341.

25. Mahar MA, Baloch WA, Jafr SIH. Diversity and seasonal occurrence of planktonic rotifers in Manchhar lake, Sindh Pakistan. Pakistan J Fish. 2000;1(1):25-32.

26. Maruthanayagam C, Sasikumar M, Senthilkumar C. Studies on zooplankton population in Thirukkulam pond during summer and rainy seasons. Nature, Environment and Pollution Technology. 2003;2(1):13-19.

27. May L, O'Hare M. Changes in rotifer species composition and abundance along a trophic gradient in loch lomond, Scotland UK. Hydrobiologia 2005;546:397404.

28. Meshram Wasudha J. Seasonal diversity of copepods in relation with physico-chemical status of Devtaki pond, Distt. Gondia, Gondia (M.S.), India. Int. J of Life Sciences. 2014;A2:147-149.

29. Mikschi E. Rotifer distribution in relation to temperature and oxygen content. Hydrobiol 1989;186/187:209-214.

30. Nayer CKG, Nair KKN. A collection of Brachionid rotifers from Kerala. Proc. Indian Acad Sci. 1969;69:223233.

31. Nilssen JP. Waeruagen SB Superficial ecosystem similarities vs autocological stripping: the "Twin species" Mesocyclops luckarti (Claus) and Thermocyclops oithonoides (Sars)-seasonal habitat utilization and life history traits. J Limnol. 2000;59:79-102.

32. Nogrady T, Wallace RL, Snell TW. Rotifera, Biology, ecology and systematics. - In: Nogrady, T., Dumont, H. (ed.) Guides to the Identification of the Micro invertebrates of the Continental Waters of the World. The Hague: SPB Academic Publishing, 1993, 1.

33. Paggi SJD. Ecological and biogeographical remarks on the rotifer fauna of Argentina. Rev. Hydrobiol. Trop. 1990;23:297-312.

34. Pennak RW. Rotifera. In: Freshwater Invertebrates of United States. 1st Edn. John Wiley and Sons, New York. 1978.

35. Peter Peduzzi, Gerhard Herndl J. Zooplankton activity fueling the microbial loop: Differential growth response of bacteria from oligotrophic and eutrophic waters. Limnol. Oceanogr. 1992;37(5):1087-109.

36. Pramod Kumar, Wanganeo A, Wanganeo R, Fozia
Sonaullah. Seasonal variations in zooplankton diversity of railway pond, Sasaram, Bihar. International Journal of Environmental Sciences. 2011;2(2):1007-1016.

37. Rundle SD, Ormerod SJ. The influence of chemistry and habitat features on some micro-crustacea of some upland Welsh streams. Freshwater Biol. 1992;26(3):439-452.

38. Sanders RW, Porter KG, Bennett SJ, DeBiase AE. Seasonal pattern of bacteriovory by flagellaes, ciliates, rotifers, and cladocerans in a freshwater planktonic community, Limnol. Oceanogr. 1989;34:673-687.

39. Santer B. Potential importance of algae in the diet of adult Cyclops vicinus. Freshwater Biol 1993;30:269-278.

40. Scheffer M, Geest GJV, Zimmer K, Jeppesen E, Sondergaard M. Small habitat size and isolation can promote species richness: Second-order effects on biodiversity in shallow lakes and ponds. Oikos. 2006;112:227-231.

41. Shah Ahmad Javaid, Pandit Ashok K. Relation between physico-chemical limnology and crustacean community in Wular lake of Kashmir Himalaya. Pakistan Journal of Biological Sciences. 2013;16:976-983.

42. Sharma BK The Indian species of the genus Brachionus (Eurotatoria: Monogononta: Brachionidae). Hydrobiologia. 1983;104:31-39.

43. Sivakami R, Sugumar R, Sumithra P, Amina S. Rotifer diversity and its seasonal variation of two perennial temple ponds of Tiruchirapalli, Tamil Nadu. Asia Pacific Journal of Research. 2013;(8):157-162.

44. Sládeček V. Rotifers as indicators of water quality. Hydrobiologia. 1983;100(1):169-201.

45. Sommer U, Stibor H. Copepoda-Cladocera-Tunicata: the role of three major mesozooplankton groups in pelagic food webs. Ecol. Res. 2002;17:161-174.

46. Stewart LJ, George DG. Environmental factors influencing the vertical migration of planktonic rotifers in zooplankton in freshwater pond Munger, Bihar. Journal of Ecobiology. 1983;5(4):299-302.

47. Vaidya Sunil Ram. Role of zooplankton in aquaculture. International Journal of Advanced Research and Development. 2017;2(5):951-954.

48. Wang CL, Wang D, Deng Zhou Z. Temporal and spatial variations in rotifer correlations with environmental factors in Shengjin Lake, China. Environ. Sci. Poll. Rese. 2016, 8076-8084. 